\title{
Filozofia, rytuał i performatywność w starożytnej myśli indyjskiej na przykładzie upaniszady Ćhandogja 6.1-6
}

\author{
Joanna Jurewicz (iD) https://orcid.org/0000-0002-9944-4140 \\ Department of Linguistics and Modern Languages \\ UNISA, Pretoria \\ Katedra Azji Południowej, Wydział Orientalistyczny \\ Uniwersytet Warszawski \\ e-mail: j.jurewicz@uw.edu.pl
}

\section{Abstract \\ Philosophy, Ritual and Performativity in Ancient Indian Thought on the Example of the Chändogya Upanișad 6.1-6}

The paper discusses cosmogony presented by Uddālaka Āruni attested in the Chāndogya Upaniṣad (6.1-6), according to which world forms arise by giving them a name. I argue that the experience that motivates the thinking of Uddālaka is ritual, the essence of which is to give people and objects a name, thanks to which their status dramatically changes for the duration of the ritual. An analysis of a selected passage of the king's coronation described in the Śatapatha Brāhmaña (5.3.4) reveals the fundamental importance of the verses uttered during preparation of the water for the consecration. The reconstruction of an experience that influences philosophical thought makes it possible to see its coherence and depth, and the fact that this experience is a ritual, a common experience of humanity, enables it to be better understood by those who grew up in other philosophical traditions as well.

Keywords: Indian philosophy, Upanișads, Brāhmaṇas, ritual, embodied cognition, performative utterances

Słowa kluczowe: filozofia indyjska, upaniszady, brahmany, rytuał, poznanie ucieleśnione, wypowiedzi performatywne 


\section{Wprowadzenie}

W niniejszym artykule analizuję, w jaki sposób codzienne doświadczenie wpływa na myślenie filozoficzne. Podstawową przesłanką dla mojego wywodu są wyniki współczesnych badań kognitywnych i neuronauk, zgodnie z którymi ludzkie poznanie jest ucieleśnione, a sposób, w jaki kategoryzujemy świat i nadajemy znaczenie, jest motywowany przez doświadczenie, zarówno biologiczne (budowa naszego organizmu), jak i osobiste, społeczne oraz kulturowe ${ }^{1}$. Z badań George'a Lakoffa i Marka Johnsona $^{2}$ wynika, że nawet podstawowe pojęcia filozofii, takie jak czas, umysł, dusza, są kształtowane pod wpływem doświadczenia. Jest ono filtrowane przez aksjomaty kulturowe przyjęte przez daną tradycję i niekwestionowane przez ogół społeczności. To od nich w dużym stopniu zależy to, jakie doświadczenie wpłynie na myślenie w danej kulturze i które jego elementy będą istotne.

Wychodząc z powyższych założeń, chciałabym omówić kosmogonię przedstawioną w upaniszadzie Ćhandogja 6.2-4. Tekst ten, ułożony w sanskrycie, powstał prawdopodobnie ok. VI wieku p.n.e. i należy do wielkiego staroindyjskiego korpusu zwanego upaniszadami. Charakterystyczne dla upaniszad jest przedstawianie treści filozoficznych w pouczeniach udzielanych przez mistrza uczniowi. Mistrz niekiedy jest ojcem ucznia, i tak jest w wypadku kosmogonii przedstawionej w Ćhandogji - włożona jest ona w usta filozofa Uddalaki Aruniego, który poucza swojego syna Śwetaketu. W swoim wywodzie Uddalaka przywołuje elementy codziennego doświadczenia, które mają ilustrować filozoficzną treść, a ściśle rzecz biorąc, kreację świata. Jak się przekonamy, związek pomiędzy przywołanym doświadczeniem a procesem stwórczym nie jest do końca oczywisty. Chciałam zaproponować tezę, że myślenie autora tej kosmogonii jest motywowane przez jeszcze inne doświadczenie, przywołane jedynie implicite, mianowicie wedyjski rytuał, a dokładniej - podstawowe dlań przekonanie, że odpowiednio wypowiedziane słowo, w odpowiednim czasie, miejscu i przez odpowiednią osobę, ma moc zmieniania natury rzeczy. To przekonanie cechuje każdy rytuał, o czym będzie mowa poniżej. Postaram się także wykazać, iż przykłady codziennych czynności podane przez Uddalakę są również pojmowane w kategoriach tak rozumianego rytualnego działania. Choć upaniszady są dziełem zbiorowym, będę używać słowa „,autor” w liczbie pojedynczej.

${ }^{1}$ A. Damasio, Descartes' Error: Emotion, Reason, and the Human Brain, New York 1996; idem, The Feeling of What Happens: Body and Emotion in the Making of Consciousness, Orlando, Austin, New York, San Diego, London 1999; idem, Self Comes to Mind: Constructing the Conscious Brain, New York 2010; idem, The Strange Order of Things: Life, Feeling, and the Making of Cultures, New York 2018.

${ }^{2}$ G. Lakoff, M. Johnson, Philosophy in the Flesh. The Embodied Mind and its Challenge to Western Thought, New York 1999. 


\section{Kosmogonia Uddalaki w upaniszadzie Ćhandogja}

Kosmogonia wprowadzona jest następująco: Syn Uddalaki, Śwetaketu, właśnie wraca z nauk, dumny ze swojej wiedzy. Tymczasem ojciec zaskakuje go pytaniem, czy skoro tak bardzo jest z siebie zadowolony - zapytał swego mistrza o wiedzę, dzięki której „to, co nieusłyszane zostaje usłyszane, niepomyślane zostaje pomyślane, a nierozpoznane rozpoznane"3. A gdy zdumiony syn pyta, czy istnieje jakieś wyjaśnienie tych kwestii, Uddalaka mówi:

To jest tak, mój drogi, jak dzięki jednej grudce gliny poznaje się wszystko, co zostało zrobione $\mathrm{z}$ gliny, przemiana bowiem to ujęcie w mowie, nadanie imienia ${ }^{4}$, a w istocie jest to glina. (4)

To jest tak, mój drogi, jak dzięki jednej ozdobie z miedzi poznaje się wszystko, co zostało zrobione $\mathrm{z}$ miedzi, przemiana bowiem to ujęcie $\mathrm{w}$ mowie, nadanie imienia ${ }^{5}$, a w istocie jest to miedź. (5)

To jest tak, mój drogi, jak dzięki jednym nożyczkom z żelaza poznaje się wszystko, co zostało zrobione z żelaza, przemiana bowiem to ujęcie w mowie, nadanie imienia ${ }^{6}$, a w istocie jest to żelazo. (6)

[Upaniszada Ćhandogja 6.1.4-6]

W powyższym fragmencie wyrażone jest przekonanie, że mnogość postrzeganych przez nas rzeczy może zostać zredukowana do ich tworzywa. Na podstawie znajomości tworzywa, z którego dana rzecz jest zrobiona, poznajemy wszystko, co z tego tworzywa powstało: dzięki grudce gliny znamy wszystko, co zrobione jest z gliny, dzięki miedzianej ozdobie to, co zrobione jest z miedzi, z kolei żelazny nożyk do paznokci ${ }^{7}$ pozwala nam poznać wszystko, co zrobione jest z żelaza. Te wszystkie przykłady wytwarzania konkretnej rzeczy są ujęte w ogólną regułę, zgodnie z którą wszelka przemiana dokonuje się w procesie nazywania, nadawania imienia. Tym, co realne i prawdziwe (satya), jest tworzywo - glina, miedź i żelazo.

Wynika stąd, że istnieją dwa poziomy percepcji świata i jego doświadczania. Na poziomie codziennego doświadczenia widzimy poszczególne obiekty, ale istnieje taki poziom, kiedy wielość rzeczy zanika i postrzegamy jedynie tworzywo, z jakiego one są zrobione. Uddalaka nie twierdzi, że wielość rzeczy jest nierealna czy fałszywa, twierdzi jedynie, że jedność ich tworzywa jest realna i prawdziwa. W sanskryckim oryginale użyty jest tu wyraz satya, oznaczający równocześnie byt i prawdę.

Następnie zostaje przedstawiona kosmogonia (6.3). Rzeczywistość, nazwana wyrazem sat, synonimicznym do wyrazu satya, kreuje świat poprzez przemianę, której stadia opisane są następująco. Pierwsze stadium jest manifestacją gorąca (tapas), drugie - manifestacją wód (āpas), trzecie - manifestacją jadła (anna). Z braku miejsca nie mogę tutaj szczegółowo omówić logiki motywującej ten proces. Najogólniej

${ }^{3}$ M. Kudelska, Upaniszady, Kraków 1999, s. 231-232.

${ }^{4}$ Ibidem: ,wszelka przemiana bowiem to tylko nazwa wynikła z mowy".

${ }^{5}$ Ibidem.

${ }^{6}$ Ibidem.

7 W sanskrycie nakhanikrntana, dosłownie „obcinacz do paznokci”. 
rzecz ujmując, odtwarza ona wypracowany już w Wedach (ok. XIII-IX w. p.n.e.) model funkcjonowania świata, zgodnie z którym słońce wznosi się na niebiosa (stadium gorąca); gdy osiągnie zenit, wylewa się z niego deszcz (stadium wód), deszcz zaś, spadając na ziemię, doprowadza do powstania jadła ${ }^{8}$. Autor kosmogonii wyraża ten model wabstrakcyjnych pojęciach, zachowując jednak jego podstawowy scenariusz .

W kolejnej fazie kreacji rzeczywistość przenika swoje manifestacje w procesie nadawania im nazwy (näman) formującej ich kształt metonimicznie identyfikowany z kolorem (rūpa, 6.4) - wszak wzrokiem poznajemy kształt rzeczy dzięki jej barwie. Dzięki temu procesowi powstają cztery świetliste zjawiska: ogień, słońce, księżyc i błyskawica. Dalej zostaje wyjaśnione, że kształt czerwony (rüpa) w tych zjawiskach jest kształtem gorąca, biały - wód, czarny - jadła.

Wynika stąd, że także w wypadku kosmosu istnieje taki punkt widzenia, w którym wielość jego zjawisk sprowadzić się daje do trzech podstawowych form. Ten punkt widzenia osiągany jest w procesie wyzwolenia i treść tego poznania nazywana jest wyrazem satya - byt-prawda. Można sądzić, że ostatecznie wyzwolony człowiek poznaje rzeczywistość (sat) w jej aspekcie nieprzejawionym i rozumie, że wszystko, co się z niej wyłoniło, jest wynikiem przemiany w kształty dzięki mocy słowa. Przyczynę, dla której używa się tutaj dwóch synonimicznych wyrazów na określenie treści poznania wyzwalającego (sat i satya), znaleźć można w innych upaniszadach: powiada się tam, że struktura wyrazu satya, który można podzielić na dwie lub trzy sylaby (w zależności od upaniszady: sat-tyam ${ }^{10}$ lub sat-ti-yam ${ }^{11}$ ), wyraża podstawowy podział kosmosu na dwa (np. niebo i ziemia) lub trzy (niebo, ziemia i łączący je przestwór) aspekty. Wyraz sat jest niepodzielny, jak niepodzielna jest rzeczywistość w swym nieprzejawionym aspekcie.

Opis stwórczych przemian zostaje podsumowany tą samą sentencją, którą Uddalaka wygłosił przy opisie przemiany tworzywa w rzeczy, a mianowicie, że przemiana jest „ujęciem w mowie, nadaniem nazwy”, naprawdę (satya) istnieją tylko te trzy podstawowe formy rzeczywistości (gorąco, wody i jadło, 6.4.5).

\section{Rytual i performatywność}

W naszym codziennym społecznym doświadczeniu zdarzają się sytuacje, kiedy słowo ma zasadniczy wpływ na status rzeczy czy osoby, zmieniając je w diametralny sposób. Jest to rozumiany szeroko rytuał, i mam tu na myśli nie tylko ten religijny. Na przykład w artykule 130 Konstytucji Rzeczypospolitej Polskiej czytamy:

${ }^{8}$ Na ten temat piszę w: J. Jurewicz, Kosmogonia Rygwedy. Myśl i metafora, Warszawa 2001; eadem, Fire and Cognition in the Rgveda, Warszawa 2010.

9 J. Jurewicz, Fire, Death and Philosophy. A History of Ancient Indian Thinking, Warszawa 2016, s. $457 \mathrm{i} \mathrm{n}$.

${ }^{10}$ Upaniszada Tajttirija 2.6.1.

${ }^{11}$ Upaniszada Ćhandogja 8.3.4-5. 
Prezydent Rzeczypospolitej obejmuje urząd po złożeniu wobec Zgromadzenia Narodowego następującej przysięgi: „Obejmując z woli Narodu urząd Prezydenta Rzeczypospolitej Polskiej, uroczyście przysięgam, że dochowam wierności postanowieniom Konstytucji, będę strzegł niezłomnie godności Narodu, niepodległości i bezpieczeństwa Państwa, a dobro Ojczyzny oraz pomyślność obywateli będą dla mnie zawsze najwyższym nakazem"12.

Człowiek, który w odpowiednim miejscu i czasie wygłosi te słowa, staje się najważniejszym członkiem polskiej społeczności, a jego sytuacja, jak również sytuacja całej społeczności, zmienia się w momencie wypowiedzenia tych słów. Jak bowiem czytamy w Konstytucji, prezydent dopiero po ich wypowiedzeniu obejmuje swój urząd. Odtąd, dla niego i dla społeczeństwa, nic już nie będzie takie jak dawniej.

W wypadku polskiego prezydenta jego własne słowa, wypowiedziane w odpowiednim miejscu i czasie, czynią go najważniejszą osobą w państwie. Natomiast podczas brytyjskiej ceremonii koronacji to arcybiskup Canterbury, wypowiadając kolejne modlitwy, ustanawia osobę obejmującą tron królem. Gdy wielebny Geoffrey Francis Fisher w 1953 roku nakładał koronę Elżbiecie II, mówił:

O God the Crown of the faithful:

Bless we beseech thee this Crown,

and so sanctify thy servant ELIZABETH

upon whose head this day thou dost place it

for a sign of royal majesty,

that she may be filled by thine abundant grace

with all princely virtues:

through the King eternal Jesus Christ our Lord ${ }^{13}$.

Odtąd życie samej Elżbiety zmieniło się diametralnie, a źródłem tej przemiany był właśnie rytuał wraz z wypowiadanymi w jego trakcie formułami. Przemianę w prezydenta czy królową można opisać słowami Uddalaki, zgodnie z którymi „przemiana jest ujęciem w mowie, nadaniem imienia".

Wyrażenia takie jak powyższe, wypowiadane w trakcie rytuału, badacze nazywają wypowiedziami performatywnymi, podkreślając istotną różnicę między nimi a wyrażeniami deskryptywnymi: podczas gdy te drugie opisują świat i mogą być oceniane pod względem ich prawdziwości, te pierwsze mogą być skuteczne lub nieskuteczne, pomyślne lub nie, gdyż wywołują, a nie opisują dany stan rzeczy ${ }^{14}$. Przy czym w umyśle uczestników rytuału moc tych wyrażeń jest sprawcza i trwa dopóty, dopóki trwa sam rytuał. W wypadku władzy państwowej obowiązują one także po jego ustaniu, a nawet po śmierci rządzącego, gdyż fakt, że ktoś był prezydentem czy królem, jest przechowywany w pamięci społeczności, co zasadniczo wpływa na sposób jego traktowania.

Problem, na ile uczestnictwo w społeczeństwie jest rytuałem, a na ile rytuał jest zabawą, analizowany m.in. przez Marka Turnera, Jana Huizingę i Rogera Caillois,

${ }^{12} \mathrm{https} / / /$ lexlege.pl/konstytucja-rzeczypospolitej-polskiej/art-130/ [dostęp: 24.04.2021].

${ }_{13} \mathrm{http}: / /$ www.oremus.org/liturgy/coronation/cor1953b.html [dostęp: 24.04.2021].

14 J.L. Austin, How to Do Things with Words, Cambridge MA 1962; J.R. Searle, Expression and Meaning, Cambridge 1979. Na temat wypowiedzi performatywnych w rytuale w świetle teorii kognitywnych zob: E. Sweetser, Blended Spaces and Performativity, „Cognitive Linguistics” 2000, nr 11, z. 3/4, s. 305-333. 
przekracza ramy niniejszej pracy ${ }^{15}$. Przywołałam przykłady przysięgi prezydenckiej oraz koronacji brytyjskiej, gdyż w wyraźny sposób ukazują one znaczenie słowa dla fundamentalnej społecznej zmiany, a zarazem są bliskie naszemu codziennemu doświadczeniu. Jak wykażę poniżej, takie doświadczenie opisywane jest również w najstarszych tekstach indyjskich.

\section{Rytuał i performatywność w opisach brahmany Śatapatha}

Proponuję założyć, że to właśnie rytuał w swym performatywnym aspekcie był doświadczeniem, które wpłynęło na myślenie autora omawianego fragmentu upaniszady Ćhandogja. Należy podkreślić, że twórcy upaniszad należeli do warstwy kapłanów (braminów) ${ }^{16}$. Odprawianie rytuału (obok codziennej recytacji Wed) było istotnym elementem ich życia, co z kolei - zgodnie ze wspomnianym na początku założeniem o ucieleśnionym charakterze poznania - musiało wywierać wpływ na sposób ich myślenia o procesach świata i ludzkich działaniach.

Jednakże autor kosmogonii Ćhandogji nie odwołuje się do rytuału explicite, a zatem, by zilustrować sposób jego pojmowania w tradycji wedyjskiej, trzeba sięgnąć do tekstów wcześniejszych, czyli brahman. Jest to wielki korpus tekstów, który powstał przed upaniszadami (ok. VIII-VII w. p.n.e.) i który stanowił egzegezę czterech najstarszych Wed. Centralnym zagadnieniem twórców brahman był właśnie rytuał. Ich autorzy nie tylko wyjaśniają szczegółowo jego przebieg, ale także jego znaczenie, poczynając od ugruntowania go w metafizycznych założeniach, a kończąc na najdrobniejszych gestach i przedmiotach, bowiem tylko ten, kto rozumie znaczenie rytuału, może liczyć na jego skuteczność.

Należy podkreślić, że był to rytuał bardzo skromny, jeśli chodzi o potrzebne do niego utensylia. Stanowiły je drewniane łyżki, drewniane lub gliniane naczynia, z bardziej cennych obiektów można wymienić płatki złota (używane m.in. właśnie w rytuale królewskiej konsekracji ${ }^{17}$. Nie budowano świątyń, placem ofiarnym był odmierzony spłacheć ziemi, uformowany tak, by opadał w kierunku wschodnim i północnym, kształtem przypominający klepsydrę, pokryty specjalną trawą, na nim budowano paleniska trzech ogni ofiarnych. Nie było także wizerunków bóstw, uobecniały się one w płonącym ogniu paleniska, do którego wlewano obiaty ${ }^{18}$.

15 V. Turner, Od rytualu do teatru. Powaga zabawy, przeł. M. i J. Dziekanowie, Warszawa 2005; idem, Gry spoleczne, pola i metafory, przeł. W. Usakiewicz, Kraków 2005; J. Huizinga, Homo ludens. Zabawa jako źródło kultury, przeł. M. Kurecka, W. Wirpsza, Warszawa 2011; R. Caillois, Człowiek i sacrum, przeł. A. Tatarkiewicz, E. Burska, Warszawa 1995; idem, Gry i ludzie, przeł. A. Tatarkiewicz, M. Żurowska, Warszawa 1997.

${ }^{16}$ Nawet gdy wprowadzali jako kszatrijów (wojowników) mistrzów udzielających pouczeń.

${ }^{17}$ Na temat zastosowania złota w dawnym Indiach zob.: J. Gonda, The Functions and the Significance of Gold in the Veda, Leiden-New York 1991.

${ }^{18}$ G.U. Thite, Sacrifice in the Brahmana-Texts, Poona 1975. Tylko w rytuale agnićajany budowano niewielki ołtarz z wypalanych cegieł i odpowiednich kamieni: J.F. Staal (coll. C.V. Somayajipad and M. Itti Ravi Nambudiri), Agni: The Vedic Ritual of the Fire Altar, Berkeley 1983, t. 1-2. 
Przygotowywanie placu ofiarnego i przedmiotów do danej ofiary było już częścią rytuału, a każdej aktywności towarzyszyły mantry, czyli wersety z Wed, recytowane również w trakcie samej ofiary. To właśnie mantry nadawały zwykłym, bardzo prostym obiektom i zachowaniom nowe nazwy, przekształcając je w coś zupełnie innego - w uosobienie aspektów mocy nieprzejawionej rzeczywistości ${ }^{19}$. Jak można sądzić, nazwy te wyrażały tajemną istotę danej rzeczy czy osoby ${ }^{20}$.

Zanalizuję teraz fragment opisu rytuału dotyczącego królewskiej konsekracji (abhișeka), mającej miejsce w czasie intronizacji królewskiej (rājasūya ${ }^{21}$, opisany w brahmanie Śatapatha. Dotyczy on przygotowywania wody, którą przyszły król będzie konsekrowany w kulminacyjnym momencie rytuału, kiedy stoi na skórze tygrysa $\mathrm{z}$ ramionami wyciągniętymi w górę, skierowany twarzą na wschód, i jest oblewany wodą z czterech stron świata przez czterech kapłanów wedyjskich oraz przez przedstawicieli określonych stanów społecznych (stanu wojowników i ludu). W akcie tym zyskuje on specyficzne cechy, dzięki którym przekształca się w króla ${ }^{22}$. Proces przygotowywania wody na konsekrację polega na wydobyciu z niej tych cech za pomocą specjalnych mantr.

Kapłan przygotowujący wodę nazywa się adhwarju. Autorzy Śatapathy wyróżniają 17 rodzajów wody, z których każda wyposaża króla w specyficzną jakość. Adhwarju pozyskuje kolejno każdy rodzaj wody, a potem zlewa je wszystkie do odpowiedniego drewnianego naczynia ${ }^{23}$, aby następnie użyć jej w trakcie konsekracji. $\mathrm{W}$ przedstawionym poniżej fragmencie ukazującym ten proces pominę opis pozyskiwania pierwszego rodzaju wody traktowanego jako woda pochodząca z rzeki Saraswati, gdyż zawiera on wiele kulturowych odniesień wymagających szczegółowego wyjaśnienia, na które w niniejszym omówieniu nie ma miejsca. Dodam, że przekład (mojego autorstwa z sanskryckiego oryginału) jest dość dosłowny, by jak najpełniej oddać opisywany w nim proces.

19 Ann Taves definiuje zjawisko religijne jako „coś, co się wyróżnia” („something that is set apart”, A. Taves, Religious Experience Reconsidered. A Building-Block Approach to the Study of Religion and Other Special Things, Princeton-Oxford 2007), i w tych kategoriach można interpretować osoby i obiekty przekształcone pod wpływem mantr.

${ }^{20}$ Na temat istoty osób i obiektów wyrażanej w tajemnym języku zob.: J. Gonda, The etymologies in the ancient Indian brāhmanas, „Lingua” 1955, t. 5, s. 61-83; Ch. Malamoud, Cooking the World. Ritual and Thought in Ancient India, Delhi 1996, s. 195-206; J. Jurewicz, What ancient Indian cosmogonies tell us about language, „Rocznik Orientalistyczny” 2012, t. 65, z. 1, s. 75-89; J. Jurewicz, Etymologies in the Brāhmanas and the Rgveda: A Case Study of 'Fire's Precedence, [w:] Vedic Investigations, A. Parpola, P. Koskikallio (red.), Delhi 2016, s. 251-270.

${ }^{21}$ J.C. Hestermann, The Ancient Indian Royal Consecration: The Rājasūya Described According to the Yajus Texts and Annoted, 's-Gravenhage 1957; P.V. Kane, History of Dharmaśästra, Poona 19681975, t. II, cz. 2.

${ }^{22} \mathrm{~W}$ podobny sposób specyficzne jakości przekazywane są brytyjskiemu władcy, w tym wypadku poprzez odpowiednie przedmioty symbolizujące te jakości, ujawniające się dzięki wypowiedzeniu odpowiedniej formuly, http://www.oremus.org/liturgy/coronation/cor1953b.html [dostęp: 24.04.2021].

${ }^{23}$ Tykwy z ciasno splecionej trzciny lub naczynia z drzewa udumbara (J. Heesterman, Ancient Indian ..., op. cit, s. 82). 


\section{Brahmana Śatapatha 5.3.4}

Wzburza wodę przed sobą i nabiera ją, mówiąc: „Jesteś falą byka, dawczynią królestwa, daj mi królestwo, swaha! Jesteś falą byka, dawczynią królestwa, daj mu królestwo". (5

Wzburza wodę za sobą i nabiera ją, mówiąc: „Jesteś wojskiem byka, dawczynią królestwa, daj mi ${ }^{24}$ królestwo, swaha! Jesteś wojskiem byka, dawczynią królestwa, daj mu królestwo!”. Tą wodą go [króla] spryskuje ${ }^{25}$, bo zaiste męstwem jest woda, która podnosi się, kiedy bydło lub człowiek do niej wchodzi, więc spryskując, męstwem go obdarza. To jeden rodzaj wody, jaką zbiera. (6)

Potem nabiera wodę płynącą z nurtem, mówiąc: „Spełniasz cel, dawczynią królestwa, daj mi królestwo, swaha! Spełniasz cel, dawczynią królestwa, daj mu królestwo". Tą wodą go opryskuje. Dzięki męstwu ona płynie i nic jej nie zatrzyma, więc męstwem go spryskując, obdarza. To jeden rodzaj wody, jaką zbiera. (7)

Potem nabiera wodę, która płynie pod prąd, mówiąc: „Jesteś pełna siły, dawczynią królestwa, daj mi królestwo, swaha! Jesteś pełna siły, dawczynią królestwa, daj mu królestwo”. Tą wodą go spryskuje. Dzięki męstwu ona płynie pod prąd, więc męstwem go spryskując, obdarza ${ }^{26}$. To jeden rodzaj wody, jaką zbiera. (8)

Potem nabiera wodę odpływającą od nurtu, mówiąc: „Jesteś tą, która zabiera, dawczynią królestwa, daj mi królestwo". Tą wodą go spryskuje. Odpłynąwszy zaiste od głównego nurtu, znowu do niego powraca, więc ktoś, kto w jego królestwie należy do innego królestwa, to on go do swojego przyciągnie. W ten sposób daje mu terytorium. Spryskując, terytorium go obdarza. To jeden rodzaj wody, jaką zbiera. (9)

Potem nabiera wodę z władcy wód (morza), mówiąc: „Jesteś władcą wód, dawcą królestwa, daj mi królestwo, swaha! Jesteś władcą wód, dawcą królestwa, daj mu królestwo". Tą wodą go spryskuje. Władca morza jest władcą, więc czyni go władcą ludów. To jeden rodzaj wody, jaką zbiera. (10)

Potem nabiera wodę z wiru, mówiąc: „Jesteś płodem wód, dawcą królestwa, daj mi królestwo, swaha! Jesteś płodem wód, dawcą królestwa, daj mu królestwo!”. Tą wodą go spryskuje. Zaiste, wody otaczają płód, w ten sposób czyni go płodem ludów. To jeden rodzaj wody, jaką zbiera. (11)

Potem nabiera wodę, która płynie w spokojnym stawie w oświetlonym przez słońce miejscu, mówiąc: „Masz słoneczną skórę, jesteś dawczynią królestwa, daj mi królestwo, swaha! Masz słoneczną skórę, jesteś dawczynią królestwa, daj mu królestwo!”. Tą wodą go spryskuje. Świetlistością spryskuje, słoneczną skórę mu daje, dlatego nią go spryskuje. To jeden rodzaj wody, jaką zbiera. (12)

Potem nabiera wodę deszczu padającego, gdy świeci słońce: „Jesteś dawczynią światłości słońca, dawczynią królestwa, daj mi królestwo, swaha! Jesteś dawczynią światłości słońca, dawczynią królestwa, daj mu królestwo!”. Spryskuje go nią - spryskuje go świetlistością

${ }^{24}$ Znane mi źródła nie wyjaśniają, dlaczego jakość najpierw ma być udzielona adhwarju, można jednakże założyć, że jest on traktowany jako swego rodzaju zbiornik na wydobytą dzięki mantrze jakość, którą potem przekaże królowi w trakcie konsekracji.

${ }_{25}$ Tekst stapia tutaj teraźniejszość i przyszłość: kapłan dopiero zbiera wodę, spryskiwać króla będzie w przyszłości, w czasie konsekracji.

${ }^{26}$ Dosłownie: ,męstwem go spryskuje”. 
słońca. Czyste są wody deszczu padającego, gdy świeci słońce, łapie je bowiem, zanim ziemi sięgną i w ten sposób czystym go czyni. To jeden rodzaj wody, jaką zbiera. (13)

Potem nabiera wodę ze stawu, mówiąc: „Jesteś upajająca, dawczynią królestwa, daj mi królestwo, swaha! Jesteś upajająca, dawczynią królestwa, daj mu królestwo!”. Spryskuje go nią w ten sposób sprawia, że lud wiernie przy nim stoi i nie opuszcza go. To jeden rodzaj wody, jaką zbiera. (14)

Potem nabiera wodę ze studni, mówiąc: „Jesteś mieszkanką stajni, dawczynią królestwa, daj mi królestwo, swaha! Jesteś mieszkanką stajni, dawczynią królestwa, daj mu królestwo!”. Spryskuje go nią. W ten sposób zbiera wody, które są poza ziemią, czyni to dla całkowitości wody, dlatego nią go spryskuje. To jeden rodzaj wody, jaką zbiera. (15)

Potem zbiera rosę, mówiąc: „Rycząca jesteś, dawczynią królestwa, daj mi królestwo, swaha! Rycząca jesteś, dawczynią królestwa, daj mu królestwo!”. Spryskuje go nią. Tym, co z jadła pochodzi ${ }^{27}$, go spryskuje i tym, co z jadła pochodzi, go obdarza. Bo słońce, kiedy wzejdzie, płonie jak ogień i spala rośliny - jadło i właśnie ta woda płynąca w dół gasi je. Gdyby ta woda nie płynęła w dół, nic z jadła by tutaj nie zostało. Właśnie tym, co z jadła pochodzi, spryskując go, obdarza ${ }^{28}$. To jeden rodzaj wody, jaką zbiera. (16)

Potem zbiera miód, mówiąc: „Jesteś najmocniejszy, dawcą królestwa, daj mi królestwo, swaha! Jesteś najmocniejszy, dawcą królestwa, daj mu królestwo!”. Spryskuje go nim - esencją wody i roślin go spryskuje. To jeden rodzaj wody, jaką zbiera. (17)

Potem bierze wody płodowe ciężarnej krowy, mówiąc: „Jesteś bykiem, dawcą królestwa, daj mi królestwo, swaha! Jesteś bykiem, dawcą królestwa, daj mu królestwo!”. Spryskuje go nim spryskując, bydłem go obdarza ${ }^{29}$. To jeden rodzaj wody, jaką zbiera. (18)

Potem nabiera mleka, mówiąc: „Żywicielem ludzi jesteś, dawcą królestwa, daj mi królestwo, swaha! Żywicielem ludzi, dawcą królestwa, daj mu królestwo!’. Spryskuje go nim - spryskując, bydłem go obdarza obdarza. To jeden rodzaj wody, jaką zbiera. (19)

Potem nabiera masła sklarowanego, mówiąc: „Żywicielem wszystkiego jesteś, dawcą królestwa, daj mi królestwo, swaha! Żywicielem wszystkiego, dawcą królestwa, daj mu królestwo!”. Spryskuje go nim - esencją bydła go spryskuje. To jeden rodzaj wody, jaką zbiera. (20)

Potemwzłożonedłoniebierzepromieniesłońcaimieszajezwodą,mówiąc:,Samowładnejesteście, dawczyniami królestwa, dajcie mi królestwo, swaha! Samowładne jesteście, dawczyniami królestwa, dawcą królestwa, daj mu królestwo!”. Promienie słoneczne są samowładną wodą, bo wydaje się, że one płyną, nie udzielając sobie wzajemnie jasności, wydaje się, że płyną raz wyżej, raz niżej. Samowładztwo w nim składa. To jeden rodzaj wody, jaką zbiera. (21)

To jest tych siedemnaście rodzajów wody, jakie zbiera. (22)

Jak widać, kategorie wody wyróżniane są na różnych zasadach. Są to: woda płynąca $\mathrm{w}$ różny sposób w odniesieniu do kapłana (z przodu i z tyłu), płynąca z prądem rzeki i pod prąd, pochodząca ze specyficznych zbiorników (studnia, staw, wir), zbierana w odpowiednim miejscu (oświetlona słonecznym światłem), w odpowiednim

\footnotetext{
${ }^{27}$ Chodzi tutaj o pochodzącą z jadła życiodajną energię.

${ }^{28}$ Dosłownie: „bydłem go spryskuje”.

${ }^{29}$ Dosłownie: „bydłem go spryskuje”.
} 
czasie (kiedy w czasie deszczu świeci słońce). Poza tym wodą są też nazywane inne rodzaje cieczy (wody płodowe, płynny miód, mleko, płynne sklarowane masło) ${ }^{30}$. Uznanie promieni słońca za wodę wynika z kulturowych przekonań: uważano, że deszczowa woda, która wypływa ze słońca, płynie na ziemię jego promieniami (i jest przez nie także z ziemi wysysana). Metonimiczne myślenie, identyfikujące pojemnik z jego zawartością, pozwala na traktowanie promieni jak wód.

Jednakże najważniejsza z punktu widzenia rytuału klasyfikacja wody i innych cieczy na różne kategorie dokonuje się w momencie wypowiedzenia mantry. Mantra, nazywając dany rodzaj cieczy (jesteś falą byka / wojskiem byka ${ }^{31}$ / spełniasz cel / jesteś pełna siły itd.), wydobywa jej istotną cechę, którą powinien zostać obdarowany przyszły król. I znowu, można opisać działalność adhwarju słowami Uddalaki: „przemiana to ujęcie w mowie, nadanie imienia, w istocie jest to tylko ciecz”. Jednak w ramach rytuału różne rodzaje cieczy - dzięki wypowiedzeniu odpowiedniej mantry nadającej nazwę (nāman) - stają się abstrakcyjnymi cechami pojmowanymi w substancjalny sposób, jako coś, co ma kształt (rüpa) ${ }^{32}$ i co - dzięki kolejnym mantrom wypowiadanym w trakcie samej konsekracji - zostanie przekazane danemu człowiekowi i przekształci go w króla.

Zatrzymajmy się na chwilę przy cechach, jakie nazywają i ujawniają mantry, co pozwoli nam dostrzec zasięg owej przemiany. Wśród nich są cechy uniwersalne dla każdej władzy, takie jak męstwo, terytorium, władza, wierność poddanych, samowładztwo. Wszelako kolejność, w jakiej są one wymieniane, odzwierciedla kosmiczny wymiar przemiany, jaka będzie zachodzić w człowieku w trakcie przyszłej konsekracji. Król bowiem w czasie konsekracji odtwarza drogę wschodzącego słońca wyrażoną we wspomnianym powyżej modelu funkcjonowania rzeczywistości. Wyposażony w podstawową cechę króla, jaką jest męstwo (5.3.4.6-8) ${ }^{33}$, startuje z ziemi (terytorium, 5.3.4.9), otrzymując władzę (5.3.4.10) daną mu przez ludzi w trakcie konsekracji. W ten sposób staje się ich potomkiem, ,płodem ludów” (3.4.11) - to oni go uczynią swoim władcą. Relacje między królem a poddanymi pojmowane są w kategoriach relacji między mężczyzną a kobietą, relacja ta zaś może być relacją matki

${ }^{30}$ W ramach wedyjskiego myślenia woda i mleko są utożsamiane ze sobą, mleko i sklarowane masło identyfikowane są na mocy metonimicznej identyfikacji tworzywa (mleka) i tego, co zeń powstaje (sklarowane masło), opisanej przez Uddalakę na początku jego wywodu.

31 W kategoriach byka pojmowani są zarówno bogowie, jak i mężczyźni, w tym królowie, poczynając już od Rygwedy; jest to prawdopodobnie dziedzictwo indoeuropejskie. Na temat metafory i metonimii pojęciowej zob.: G. Lakoff, Kobiety, ogień i rzeczy niebezpieczne. Co kategorie mówia nam o umyśle, przeł. M. Buchta, A. Kotarba, A. Skucińska, Kraków 2011; G. Lakoff, M. Johnson, Metafory w naszym życiu, przeł. T. Krzeszowski, Warszawa 2010; Metonymy in Language and Thought, K.-U. Panther, G. Radden (red.), Amsterdam-Philadephia 1999.

${ }^{32}$ Na temat substancjalności abstrakcyjnych pojęć zob.: S. Schayer, O genezie monizmu Upaniszad z magicznego światopogladu Atharwa-Wedy i Brahmanów, [w:] O filozofowaniu Hindusów: artykuty wybrane, M. Mejor (red.), Warszawa 1988, s. 13-22.

33 Pojęcie męstwa (vīrya) konotowało również znaczenie ruchu w górę i stania prosto; J. Jurewicz, Visual Culture, [w:] A Cultural History of Hinduism in Antiquity (2000-200 BCE), J. Whitaker (red.), London (w druku). 
i dziecka, kochanki i kochanka oraz córki i ojca ${ }^{34}$. Cecha nazwana „płodem ludów” przywołuje pierwszy typ tej relacji: władca rodzi się dzięki poddanym. W kategoriach narodzin pojmowany jest też wschód słońca: nocne niebo jest rodzicielką słońca, a zatem król równocześnie pojmowany jest jako wschodzące słońce. W trakcie swojej przemiany sięga on wraz ze słońcem zenitu, jednak będąc człowiekiem, potrzebuje ochrony przed palącym gorącem, którą da mu słoneczna skóra (5.3.4.12). Na słońcu w zenicie stanie się on świetlisty i w stanie upajającej radości (5.3.4.13-14) ${ }^{35}$. Dzięki tej transformacji przyszły król będzie się cieszył wiernością ludu (5.3.4.14). Ten proces jego wędrówki w górę wyraża wzniesienie przez niego ramion.

We fragmencie 5.3.4.15 woda ze studni nazwana jest mieszkanką stajni, a przyszły król łączy się z pozaziemskimi wodami, które znajdują się na słońcu. Wyrażenie „mieszkanka stajni” przywołuje pojęcie krowy, a w tym wypadku metonimicznie jej wymienia, w kategoriach którego pojmowano słońce: z jego czterech sutków wypływały cztery strugi deszczu ${ }^{36}$. W ten sposób rozpoczyna się druga część wędrówki przyszłego króla - w dół, z powrotem na ziemię.

Jak wspomniałam powyżej, w bramińskim modelu funkcjonowania świata, gdy słońce osiągnie zenit, powstaje z niego deszcz. I tę właśnie ideę przywołuje pojęcie pozaziemskich wód, w które wyposażony zostaje król w trakcie swej transformacji. Rosa określona zostaje jako rycząca ( $v a \bar{s} s a, 5.3 .4 .16$ ), co przywołuje zarówno ryk grzmotu zapowiadającego deszcz, jak i ryk bydła, które żywi się trawą rosnącą po deszczu, lecz także jest znakiem bogactwa. Deszcz stanowi źródło życiodajnych funkcji jadła (,to, co pochodzi z jadła”, 5.3.4.16, „esencja wód i jadła”, 5.3.4.17), manifestujących się w roślinach, rośliny też żywią bydło (5.3.4.18). „Esencja bydła” (5.3.4.19) może odnosić się zarówno do życiodajnej funkcji jego mięsa ${ }^{37}$, jak i do wspomnianego przed chwilą faktu, że bydło było najważniejszym elementem bogactwa. Powracający na ziemię przyszły król, w drugim etapie swej transformacji, staje się źródłem tych wszystkich dóbr. Zarazem, jako ich właściciel, będzie żywicielem wszystkich poddanych (ŚB 5.3.4.19) i niezależnym samodzielnym władcą (ŚB 5.3.4.20). W ten sposób rytuał identyfikuje przyszłego króla z cyklem kosmosu oraz funkcjonowaniem społeczeństwa.

Opisane powyżej znaczenie wyraża się w mantrach recytowanych przez kapłana w trakcie zbierania wody. Jednak nie tylko o znaczenie tu chodzi. Można przypuszczać, że dla uczestników rytuału była to przemiana rzeczywista, podobnie jak rzeczywista przemiana dokonuje się w trakcie przysięgi prezydenckiej czy dzięki modlitwie arcybiskupa. Człowiek stojący ze wzniesionymi ramionami i polewany wodą

${ }^{34}$ Ściślej rzecz biorąc, pierwiastek żeński jest mnogi, podczas gdy pierwiastek męski pojedynczy. Wyraża się to w semantyce sanskryckiego rzeczownika ap, „woda”, używanego zawsze w liczbie mnogiej. Zob.: J. Jurewicz Kosmogonia..., op. cit., s. 341-366, idem, Fire and Cognition..., op. cit., s. 203-215.

${ }^{35}$ Stan upajającej radości, jaki osiąga człowiek na słońcu, przywołuje stan upojenia somą opisywany przez poetów Rygwedy, zob.: J. Jurewicz, Fire and Cognition ..., op. cit., s. 177-182.

${ }^{36}$ J. Jurewicz, The cow's body as the source domain of philosophical metaphors in the Rgveda. The case of 'udder' (üdhar), [w:] The Body in Language Comparative Studies of Linguistic Embodiment, M. Brenzinger, I. Kraska-Szlenk (red.), Leiden 2014, s. 98-116.

${ }^{37}$ Hinduizm wedyjski nie zalecał wegetarianizmu, składano również ofiary ze zwierząt. 
$\mathrm{z}$ drewnianych kubków stawał się nie tylko królem, lecz także uosabiał axis mundi oraz - metonimicznie - cały aspekt przejawiony rzeczywistości. Przemiana ta miała zasadniczy wpływ na jego sytuację, sytuację całej społeczności oraz kosmosu.

\section{Rytualna performatywność jako doświadczenie motywujące myślenie Uddalaki}

Powyższy opis brahmany Śatapathy ukazuje jasno, że w obrębie rytuału przemiana stanowi „ujęcie w mowie, nadanie imienia” - zgodnie z definicją podaną przez Uddalakę. $Z$ perspektywy codziennego doświadczenia istnieje woda i inne rodzaje cieczy, jak mleko czy miód, oraz promienie słoneczne. $Z$ perspektywy rytualnej zaś istnieje siedemnaście abstrakcyjnych jakości. Ciecz dzięki nazwie (nāma) wypowiedzianej w mantrze przyjmuje nowy kształt (rüpa). Ale naprawdę, na poziomie satya, istnieje tylko ciecz.

Można zatem uznać, że to właśnie rytuał był doświadczeniem, które motywowało myślenie autora Ćhandogji, gdy tworzył swoją teorię powstania świata. W brahmanach każda kosmogonia explicite przedstawia kreację jako pierwsze odprawienie ofiary przez Stwórcę. Jak wspomniałam powyżej, kosmogonia upaniszady Ćhandogja jest abstrakcyjnym ujęciem wcześniejszego myślenia: jak szczegółowy model stwórczych i kosmicznych przekształceń uzyskuje tutaj formę przemiany gorąca w wody, a wód w jadło, tak rytuał zostaje sprowadzony do swej najistotniejszej cechy, jaką jest sprawianie, że nadanie nazwy zmienia status człowieka czy obiektu w zasadniczy dla społeczności sposób.

Powróćmy teraz do przykładów podanych na początku kosmogonii, które mają ilustrować naturę kreacji, a które opisują codzienne tworzenie rzeczy. Przecież tworzenie naczynia jest czymś więcej niż tylko nadaniem nowej nazwy grudzie gliny, podobnie jak nie wystarczy nazwać jakiś metal, by stworzyć z niego nożyk do paznokci czy ozdobę. A jednak autor kosmogonii w tym właśnie upatruje podobieństwa między tworzeniem rzeczy i tworzeniem świata: w nadaniu nazwy, która doprowadza do przemiany - tak jak ma to miejsce w rytuale. Zaproponuję teraz możliwy sposób myślenia, który uzasadniał jego przekonanie.

Można powiedzieć, że każdy ludzki proces twórczy zaczyna się od nazwania w myślach przyszłego projektu, jak na przykład „Zrobię naczynie!” lub po prostu: „Naczynie!”. Wszystkie dalsze działania rzemieślnika, w wyniku których powstanie rzecz o konkretnym kształcie (rüpa), są skutkiem pierwszego nazwania (nāman) leżącej przed nim grudy gliny czy kawałka metalu. Tak samo rzecz się ma w wypadku kreacji świata: jest skutkiem myśli: „Chcę, żeby było mnie więcej, chcę się rozmnożyć!" ${ }^{38}$. Jeśli zgodzimy się na taką interpretację, dostrzeżemy, jak wielką rolę w swojej teorii tworzenia Uddalaka przypisuje pierwszemu poznawczemu impulsowi, który zapoczątkowuje istnienie świata i wszystkich rzeczy złożonych, wtórnych

${ }^{38}$ Działanie twórcze rzeczywistości (sat) poprzedza pragnienie zwielokrotnienia i rozmnożenia siebie (tad aikșata | bahu syām prajāyeyeti). 
niejako wobec myśli i nazwy. Co więcej, choć nie mamy świadectw dotyczących codziennej wytwórczości z czasów brahman i upaniszad, można przypuszczać, że były one traktowane także jako aktywność rytualna, a tajemnica rzemiosła była przekazywana $\mathrm{z}$ ojca na syna ${ }^{39}$. W każdym razie sentencja Uddalaki zastosowana w odniesieniu do nicha sugeruje nam, że - przynajmniej w oczach twórców upaniszady - każda ludzka twórcza aktywność jest rytuałem w sensie, o jakim mówiłam powyżej.

Interpretację tę potwierdza też semantyczna analiza wyrazu ārambhana, użytego w sentencji ,przemiana to ujęcie w mowie, nadanie nazwy" (väcärambhaṇam vikāro nāmadheyam ). Badacze różnie interpretują jego znaczenie, podobnie jak gramatyczną naturę samego złożenia vācārambhaṇam i całego zdania ${ }^{40}$, warto jednak zwrócić uwagę, że pierwszym znaczeniem czasownika a rambh-, od którego pochodzi ten rzeczownik, jest „chwytać, łapać”, ārambhaṇa zatem znaczy dokładnie to samo, co polskie ,ujęcie, chwytanie, łapanie”. Wyrażenie myśli w mowie pojmowane jest w kategoriach chwytania tego, co jest nazywane, i oba języki, polski i sanskryt, zaświadczają tę metaforę ${ }^{41}$. Można sądzić jednak, iż w kontekście wywodu Uddalaki doświadczeniowy scenariusz był łatwiej przywoływany niż w wypadku polszczyzny: wypowiedzenie myśli pojmowane było nie tylko jako jej pochwycenie, ale też jako wyniesienie jej na zewnątrz umysłu, tak by otrzymała widzialny kształt (rūpa), jak to miało miejsce w wypadku ujawnienia istotnej cechy danej cieczy dzięki wypowiedzeniu mantry. Zgadza się to ze scenariuszem tworzenia rzeczy, zgodnie z którym po powstaniu pomysłu należy wziąć narzędzie do ręki, by nadać pomysłowi kształt.

Jak zwraca uwagę Patrick Olivelle, w upaniszadach wyraz ārambhana używany jest w znaczeniu ,podstawa”" ${ }^{\text {"2 }}$. Pojęcie podstawy rozumiane jest w Wedzie jako punkt wyjścia do dalszych działań (przede wszystkim działań stwórczych, np. brahmana Śatapatha $6 \cdot 1 \cdot 1.8^{43}$ ). Zapewne tutaj należy upatrywać źródeł kolejnego znaczenia wyrazu ārambhana, jakim jest „początek, rozpoczęcie działania”. Biorąc je pod uwagę, można uznać, że autor kosmogonii także implikuje, iż początkiem wszelkiej przemiany jest nadanie nazwy. Wszystkie te znaczenia zbiegają się z opisanym powyżej scenariuszem zarówno pracy rzemieślniczej, jak i rytualnego działania.

39 M. Eliade, Kowale i alchemicy, przeł. A. Leder, Warszawa 2010.

${ }^{40} \mathrm{Na}$ ten temat zob.: J.A.B. van Buitenen, Studies in Indian Literature and Philosophy, L. Rocher (red.), Delhi 1988, s. 5-12, 121-134; F.B.J. Kuiper, Vācārambhaṇam, „Indo-Iranian Journal” 1957, t. 1, z. 2, s. 154-159; Vācārambhaṇam (II), „Indo-Iranian Journal” 1958, t. 2, z. 4, s. 306-310; P. Olivelle, Upanișads; Translated from the Original Sanskrit, Oxford 1996, s. 558.

41 Na przykład: „Nie mogę załapać, o co ci chodzi”. Używam tutaj terminu „,metafora” w znaczeniu, jakie przypisuje mu lingwistyka kognitywna, czyli w znaczeniu procesu mentalnego pozwalającego na rozumienie jednego pojęcia w kategoriach innego (poznanie to chwytanie, G. Lakoff, M. Johnson, Metafory..., op. cit.; eadem, Philosophy..., op. cit.

${ }^{42}$ P. Olivelle, Upaniṣads..., op. cit. Sam idzie w swoim przekładzie za Franklinem Edgertonem (The Beginnings of Indian Philosophy: Selections from the Rig Veda, Atharva Veda, Upanisad, and Mahabharata, London 1965) i tłumaczy vācārambhanam jako ,verbal handle”.

43 J. Jurewicz, Etymologies..., op. cit. 


\section{Podsumowanie}

Z przedstawionej analizy wynika, iż autor kosmogonii ukazanej w upaniszadzie Ćhandogja stosuje pojęcie przemiany społecznej w rytuale do opisu przeobrażeń ontologicznych. Rzeczywistość dzięki nadaniu nazwy staje się kosmosem, podobnie jak w trakcie konsekracji wedyjskiej, koronacji brytyjskiej czy przysięgi prezydenckiej dany człowiek staje się kimś innym. Autor kosmogonii nie nawiązuje bezpośrednio do rytuału, ale inspirowany jest jego podstawową performatywną mocą i w tych kategoriach rozumie powstanie świata: jako postrzegalny skutek nadania nazwy.

Takie rozumienie kreacji pozwala mu na rozróżnianie poziomów poznania. Na co dzień mamy do czynienia z wielością ról społecznych, wielością obiektów o różnym znaczeniu, jednak istnieje poziom poznawczy, na którym ta wielość daje się sprowadzić do bardziej ogólnych pojęć, kiedy na przykład uświadamiamy sobie, że król to też człowiek. Opis Ćhandogji implikuje istnienie poziomów doświadczenia codziennego (kiedy widzimy wielość rzeczy) i wychodzącego poza nie (kiedy wielość rzeczy sprowadza się do trzech manifestacji: gorąca, wód i jadła, poziom zwany satya). Najwyższym poziomem, uzyskiwanym w poznaniu wyzwalającym, jest ten, kiedy doświadcza się istnienia jedności wyrażonej w pojęciu sat.

Autor kosmogonii stosuje pojęcie rytualnej przemiany społecznej także w odniesieniu do tworzenia materialnych obiektów. W ten sposób wszelka twórcza aktywność daje się wyrazić w jednym scenariuszu. Warto dodać, że kolejne dwa podrozdziały (6.5-6) przedstawiają obecność kosmicznych trzech form rzeczywistości w człowieku (umysł to jadło, oddech to woda, a mowa to gorąco), co poszerza zakres scenariusza o procesy poznawcze zachodzące $\mathrm{w}$ człowieku ${ }^{44}$. $\mathrm{Z}$ punktu widzenia rozwoju wczesnej filozofii indyjskiej można powiedzieć, że zastosowanie pojęcia rytualnej performatywności pozwala autorowi kosmogonii na daleko idącą abstrakcję swojej teorii świata i człowieka.

Rekonstrukcja doświadczenia wpływającego na filozoficzną myśl daje możliwość dostrzeżenia jej spójności i głębi, fakt zaś, że tym doświadczeniem jest rytuał, doświadczenie wspólne ludzkości, umożliwia lepsze jej zrozumienie także tym, którzy wychowali się w innych filozoficznych tradycjach. Ostatecznie jako członkowie społeczeństwa żyjemy w świecie, w którym nadawanie nazwy osobom, rzeczom czy procesom sprawia, że zgadzamy się na ich inne znaczenie, co więcej, żyjemy tak, jakby były one rzeczywiście czymś innym, niż są „tak naprawdę”, kiedy się je pozbawi społecznego kontekstu.

44 Poznanie dokonywało się w trakcie recytacji Wedy, a zatem było wspólną aktywnością umysłu, oddechu i mowy. 


\section{Bibliografia}

\section{Źrodła}

Brahmana Śatapatha, http://titus.uni-frankfurt.de/texte/etcs/ind/aind/ved/yvw/sbm/sbm.htm [dostęp: 24.04.2021].

Upaniszada Ćhandogja, http://titus.uni-frankfurt.de/texte/etcs/ind/aind/ved/sv/upanisad/chup/chup. htm [dostęp: 24.04.2021].

\section{Opracowania}

Austin J.L., How to Do Things with Words, Cambridge MA 1962.

Buitenen J.A.B. van, Studies in Indian Literature and Philosophy, L. Rocher (red.), Delhi 1988.

Caillois R., Człowiek i sacrum, przeł. A. Tatarkiewicz, E. Burska, Warszawa 1995.

Caillois R., Gry i ludzie, przeł. A. Tatarkiewicz, M. Żurowska, Warszawa 1997.

Edgerton F., The Beginnings of Indian Philosophy: Selections from the Rig Veda, Atharva Veda, Upanisad, and Mahabharata, London 1965.

Eliade M., Kowale i alchemicy, przeł. A. Leder, Warszawa 2010.

Damasio A., Descartes' Error: Emotion, Reason, and the Human Brain, New York 1996.

Damasio A., The Feeling of What Happens: Body and Emotion in the Making of Consciousness, Orlando-Austin-New York-San Diego-London 1999.

Damasio A., Self Comes to Mind: Constructing the Conscious Brain, New York 2010.

Damasio A., The Strange Order of Things: Life, Feeling, and the Making of Cultures, New York 2018.

Gonda J., The etymologies in the ancient Indian brāhmanas, „Lingua” 1955, t. 5, s. 61-83.

Gonda J., The Functions and the Significance of Gold in the Veda, Leiden-New York 1991.

Hestermann J.C., The Ancient Indian Royal Consecration: The Rājasūya Described According to the Yajus Texts and Annoted, 's-Gravenhage 1957.

Huizinga J., Homo ludens. Zabawa jako źródto kultury, przeł. M. Kurecka, W. Wirpsza, Warszawa 2011.

Jurewicz J., Etymologies in the Brāhmanas and the Rgveda: A Case Study of 'Fire's Precedence, [w:] Vedic Investigations, A. Parpola, P. Koskikallio (red.), Delhi 2016, s. 251-270.

Jurewicz J., Fire and Cognition in the Rgveda, Warszawa 2010.

Jurewicz J., Fire, Death and Philosophy. A History of Ancient Indian Thinking, Warszawa 2016.

Jurewicz J., Kosmogonia Rygwedy. Myśl i metafora, Warszawa 2001.

Jurewicz J., What ancient Indian cosmogonies tell us about language, „Rocznik Orientalistyczny” 2012 , t. 65 , z. 1 , s. $75-89$.

Jurewicz J., Visual Culture, [w:] A Cultural History of Hinduism in Antiquity (2000-200 BCE), J. Whitaker (red.), London (w druku).

Jurewicz J., The cow's body as the source domain of philosophical metaphors in the Rgveda. The case of 'udder' (üdhar), [w:] The Body in Language Comparative Studies of Linguistic Embodiment, M. Brenzinger, I. Kraska-Szlenk (red.), Leiden 2014, s. 98-116.

Kane P.V., History of Dharmaśāstra, Poona 1968-1975, t. 2, cz. 2.

Kudelska M., Upaniszady, Kraków 1999.

Kuiper F.B.J., Vācārambhanam, „Indo-Iranian Journal” 1957, t. 1, z. 2, s. 154-159.

Kuiper F.B.J., Vācārambhaṇam (II), „Indo-Iranian Journal” 1958, t. 2, z. 4, s. 306-310. 
Lakoff G., Kobiety, ogień i rzeczy niebezpieczne. Co kategorie mówia nam o umyśle, przeł. M. Buchta, A. Kotarba, A. Skucińska, Kraków 2011.

Lakoff G., Johnson M., Metafory w naszym życiu, przeł. T. Krzeszowski, Warszawa 2010.

Lakoff G., Johnson M., Philosophy in the Flesh. The Embodied Mind and its Challenge to Western Thought, New York 1999.

Malamoud Ch., Cooking the World. Ritual and Thought in Ancient India, Delhi 1996.

Metonymy in Language and Thought, K.-U. Panther, G. Radden G. (red.), Amsterdam-Philadephia 1999.

Olivelle P., Upanișads; Translated from the Original Sanskrit, Oxford 1996.

Schayer S., O genezie monizmu Upaniszad z magicznego światopogladu Atharwa-Wedy i Brahmanów, [w:] O filozofowaniu Hindusów: artykuly wybrane, M. Mejor (red.), Warszawa 1988, s. 13-22.

Searle J.R., Expression and Meaning, Cambridge 1979.

Staal J.F. (coll. C.V. Somayajipad and M. Itti Ravi Nambudiri), Agni: The Vedic Ritual of the Fire Altar, Berkeley 1983, t. 1-2.

Sweetser E., Blended Spaces and Performativity, „Cognitive Linguistics” 2000, nr 11, z. 3/4, s. 305-333.

Taves A., Religious Experience Reconsidered. A Building-Block Approach to the Study of Religion and Other Special Things, Princeton-Oxford 2007.

Thite G.U., Sacrifice in the Brahmana-Texts, Poona 1975.

Turner V., Od rytualu do teatru. Powaga zabawy, przeł. M. i J. Dziekanowie, Warszawa 2005.

Turner V., Gry spoleczne, pola i metafory, przeł. W. Usakiewicz, Kraków 2005.

https://lexlege.pl/konstytucja-rzeczypospolitej-polskiej/art-130/ [dostęp: 24.04.2021].

http://www.oremus.org/liturgy/coronation/cor1953b.html [dostęp: 24.04.2021]. 